Teologia i Moralność, volumen 12(2017), numer 2(22)

doi: 10.14746/tim.2017.22.2.17

DARIUSZ KWIATKOWSKI

Uniwersytet im. Adama Mickiewicza w Poznaniu

Wydział Teologiczny

\title{
Kult adoracji eucharystycznej źródłem autentycznych chrześcijańskich postaw moralnych
}

Reforma liturgiczna Soboru Watykańskiego II przyczyniła się do bardziej świadomego, czynnego i przez to bardziej owocnego uczestnictwa wiernych w Eucharystii. Uczestnictwo w Eucharystii oraz adoracja Najświętszego Sakramentu są dla wiernych niewyczerpanym źródłem świętości i kształtowania właściwych postaw moralnych. Jan Paweł II w encyklice Ecclesia de Eucharistia ukazuje różne aspekty świętości chrześcijańskiego życia czerpiącej swoje źródło z Eucharystii. Źródłem tej świętości jest zjednoczenie z Chrystusem w Komunii Świętej oraz dar Ducha Świętego. Uczestnictwo w życiu Trójcy Świętej, w której wierny uczestniczy, przyjmując Komunię Świętą, ma konkretne implikacje moralne odnoszące się do codziennego chrześcijańskiego życia.

Święty Jan Paweł II w zakończeniu encykliki Ecclesia de Eucharistia, mówiąc o zadaniach duszpasterskich dla całego Kościoła, napisał: „Nie trzeba wyszukiwać nowego programu. Program już istnieje: ten sam co zawsze, zawarty w Ewangelii i w żywej Tradycji. Jest on skupiony w istocie rzeczy wokół samego Chrystusa, którego mamy poznawać, kochać i naśladować, aby żyć w Nim życiem trynitarnym i z Nim przemieniać historię, aż osiągnie swą pełnię w niebieskim Jeruzalem. Wypełnianie tego programu odnowionej gorliwości w życiu chrześcijańskim wiedzie przez Eucharystię"1. Papież zwraca uwagę także, że każdy krok ku świętości, każde działanie ewangelizacyjne oraz osobista duchowość powinna czerpać potrzebną siłę z Eucharystii. Chrze-

${ }^{1}$ Jan Paweł II, Encyklika o Eucharystii w życiu Kościoła Ecclesia de Eucharistia, Poznań 2003, n. 60 (dalej: EE). 
ścijańskie życie, duchowość chrześcijańska winny stawać się eucharystycznymi. Wezwanie to podjął także dokument przeznaczony na XI Synod Biskupów. Czytamy w nim, że by uczynić eucharystycznym życie chrześcijańskie wierni powinni Eucharystię coraz bardziej poznawać, by ją bardziej kochać i w konsekwencji nią żyć ${ }^{2}$.

Kult eucharystyczny jest bardzo bogaty i przyjmuje różne formy, z których najważniejsza jest oczywiście celebracja Eucharystii. Z niej jednak wyrastają inne formy, do których możemy zaliczyć: udzielanie Komunii poza Mszą Świętą, adorację Najświętszego Sakramentu, kongresy eucharystyczne i procesje eucharystyczne. Wydaje się, że poza uczestnictwem w Eucharystii, przyjmowaniem Komunii Świętej najważniejszą formą kultu eucharystycznego pomagającą $\mathrm{w}$ kształtowaniu autentycznych chrześcijańskich postaw moralnych jest adoracja Najświętszego Sakramentu.

Święty Jan Paweł II w encyklice o Eucharystii przypomina wielu świętych, którzy swoją świętość budowali na adoracji Chrystusa eucharystycznego i daje osobiste świadectwo, że sam wielokrotnie przeżywał to doświadczenie i dzięki niemu otrzymywał siłę, pociechę i wsparcie ${ }^{3}$. Natomiast św. Alfons Maria Liguori pisał: „Wśród różnych praktyk pobożnych adoracja Jezusa sakramentalnego jest pierwsza po sakramentach, najbardziej Bogu miła i najbardziej pożyteczna dla nas"4. Celem artykułu jest ukazanie wielkiej mocy płynącej z adoracji Najświętszego Sakramentu. Modlitwa spędzona przed obliczem Chrystusa obecnego w Eucharystii jest konieczna do budowania osobistej świętości i życia według zasad Ewangelii. Otwiera także nowe drogi dla chrześcijańskiego życia i świadczenia o eucharystycznej miłości Chrystusa ukrytego w Najświętszym Sakramencie.

\section{Konieczność kultu eucharystycznego w życiu chrześcijanina}

Nie ulega wątpliwości, że adorowana Eucharystia kształtuje chrześcijańskie życie wszystkich tych wiernych, którzy oddają jej cześć. Jezus pozostał ze swoimi uczniami w Eucharystii na zawsze, by nieustannie ich wspierać na drodze do osiągnięcia życia wiecznego. Ta nieustająca obecność Jezusa zawsze wzbudzała i wciąż wzbudza w Jego uczniach pragnienie zjednoczenia się z Nim i między sobą. Staje się to źródłem postawy czynnej miłości, która

${ }^{2}$ Zob. XI Zwyczajne Zgromadzenie Biskupów, Eucharystia: źródlo i szczyt życia i postannictwa Kościoła. Zarys, Watykan 2004, 2.

${ }^{3}$ Por. EE 25.

${ }^{4}$ A.M. Liguori, Visite al. SS. Sacramento ed a Maria Santissima. Introduzione, w: Opere ascetiche, Avellino 2000, s. 295. 
jest najważniejszą chrześcijańską cnotą i najważniejszym przykazaniem danym przez samego Jezusa (por. Mt 22,34-40). Umiłowanie Eucharystii stanowi swoisty wyznacznik Kościoła katolickiego. Spośród wszystkich wyznań chrześcijańskich to właśnie jemu, w sposób wyjątkowy, jako szczególny dar Ducha Świętego, został przekazany kult eucharystyczny. Mając to na uwadze, winien on więc nie tylko strzec tej pobożności, ale również promieniować jej owocami na wszystkich chrześcijan ${ }^{5}$. W ten sposób Eucharystia ujawnia się jako Sakrament budujący jedność wyznawców Chrystusa, o którą prosił On swego Ojca (zob. J 17,20-23).

Jezus uwielbiony w Najświętszej Eucharystii nieustannie uzdalnia wiernych do opanowywania namiętności i przeciwstawianiu się pokusom. Pobudzając wszystkich, którzy się do Niego zbliżają, aby Go naśladowali, pragnie On, by wszyscy synowie Kościoła stanowili jedno i byli jednomyślni ${ }^{6}$. To pragnienie Zbawiciela, wyrażone w słowach Modlitwy Arcykapłańskiej (zob. J 17,1-26) i ukazujące uniwersalny charakter chrześcijaństwa, winno przynaglać wszystkich Jego uczniów do uczestnictwa w tej Tajemnicy?.

Potrzeba kultu eucharystycznego wypływa nie tyle z nakazu Zbawiciela (zob. Łk 22, 19), ile raczej z doczesnej sytuacji człowieka. Doświadczenie tego, że wciąż pielgrzymuje on do domu Ojca (zob. J 14,2-4) każe mu wołać wraz z uczniami idącymi do Emaus: „Zostań z nami Panie” (por. Łk 24,29). $\mathrm{W}$ odpowiedzi na tę prośbę ,W pokornym znaku chleba i wina, przeistoczonych w Jego Ciało i Jego Krew, Chrystus wędruje razem z nami, jako nasza moc i nasz wiatyk, i czyni nas świadkami nadziei dla wszystkich"8. Podobnie jak manna wybawiła Izraelitów od śmierci głodowej na pustyni (zob. Wj 16,4.13-15), tak samo Eucharystia - prawdziwy chleb z nieba (por. J 6,33.41.48-51) - podtrzymuje życie nowego Ludu Bożego zmierzającego do

${ }^{5}$ Por. EE 25; 60. Obok przywiązywania dużej wagi do prawodawstwa, stał się on cechą wyróżniającą Kościół katolicki od pozostałych wyznań chrześcijańskich. We wspólnotach protestanckich bowiem na pierwszy plan wysuwa się odniesienie do Pisma Świętego. Kościół prawosławny natomiast zachował pierwotne ukierunkowanie na misterium. Pomimo różnych relacji tych Kościołów do omawianego zagadnienia świadczy to o bogactwie Mistycznego Ciała Chrystusa.

${ }^{6}$ Zob. Paweł VI, Encyklika Mysterium fidei, w: To czyńcie na moja pamiątkę. Eucharystia w dokumentach Kościoła, oprac. J. Miazek, Warszawa 1987, s. 29-32.

7 Wymiar ekumeniczny i jednoczący tego sakramentu uwidacznia się w wielu momentach życia Kościoła. Przejawem takiego właśnie spojrzenia na Eucharystię był między innymi wspólny udział katolików i prawosławnych w procesji eucharystycznej w Opolu w 1985 roku. Wydarzenie to miało miejsce z okazji obrad Komitetu Koordynacyjnego Międzynarodowej Komisji Mieszanej do dialogu teologicznego między Kościołem Rzymskokatolickim i Kościołem prawosławnym. Por. M. Blaza, Wszyscy jesteśmy ludem Eucharystii, „Przegląd Powszechny” 922(1998), s. 265-276. Należy jednak pamiętać, że rzeczywista interkomunia winna zawsze stanowić cel owego dążenia do jedności, a nigdy środek prowadzący do niego. Por. EE 44.

${ }^{8}$ EE 62. 
niebieskiej ojczyzny. Ten Pokarm dający siłę do dalszej pielgrzymki Kościół od swego początku otacza niezmienną czciąa .

Sakrament ten nie tylko stanowi umocnienie chrześcijan w doczesności, ale staje się już teraz, w tym czasie, antycypacją dóbr przyszłych i swego rodzaju bramą nieba. Eucharystia, którą Mistyczne Ciało Chrystusa adoruje również poza Mszą św., jest już teraz „,promieniem chwały niebieskiego Jeruzalem, który przenika cienie naszej historii i rzuca światło na drogi naszego życia" ${ }^{10}$. To eschatologiczne odniesienie pozwala widzieć w tym Sakramencie porywającą siłę, która pozwala iść drogą chrześcijańską z nadzieją. Taka relacja do Najświętszego Sakramentu owocuje rzeczywistą komunią zaspokajającą głód odczuwany przez ludzką duszę i pozwala sycić się Bogiem na tej Ziemi w oczekiwaniu na pełne zaspokojenie w niebie ${ }^{11}$.

Adorację Chrystusa w Najświętszym Sakramencie należy widzieć jako pragnienie przylgnięcia do źródła największej Miłości i całkowitego zanurzenia się w niej. Poczucie bezpieczeństwa, jakie staje się wówczas udziałem modlącego się człowieka, stanowi Bożą odpowiedź na doświadczenie jego niemocy. Wymaga to jednak od człowieka nie tylko przystąpienia do Zbawiciela, ale takiego zespolenia, aby tworzyć z Nim jedno Ciało. W przeciwnym razie w miejsce prawdziwego kultu eucharystycznego wkroczy zwykły rytualizm. Ogromny wpływ na wartość i uświęcającą moc płynącą z tych form pobożności ma więc postawa wewnętrzna uczestników ${ }^{12}$. Bez tego ich zaangażowania trudno jest mówić o życiu prawdziwie eucharystycznym, a przez to chrześcijańskim. Jan Paweł II w encyklice o Eucharystii tak pisze o tym zespoleniu się z Chrystusem: „Pięknie jest zatrzymać się z Nim i jak umiłowany Uczeń oprzeć głowę na Jego piersi (por. J 13,25), poczuć dotknięcie nieskończoną miłością Jego Serca"13.

Kult adoracji eucharystycznej nie wyczerpuje się tylko i wyłącznie na modlitwie przed obliczem Chrystusa obecnego w znaku chleba. Ta modlitwa winna prowadzić do całkowitego zjednoczenia się z Panem w codziennym życiu, dokonywanych wyborach i ludzkich postawach. Najbardziej weryfikuje się ono poprzez czynną miłość bliźniego (zob. $1 \mathrm{~J}$ 4,20). Postawa służby,

${ }^{9}$ Prawdę tę odzwierciedlają teksty licznych pieśni eucharystycznych. Na uwagę zasługuje refren pieśni: Lud Twój, Panie: „Lud Twój, Panie, lud pielgrzymi, Prosi, byś był światłem, Byś na drodze do Królestwa wzmacniał serca swoim Ciałem", w: Exsultate Deo. Śpiewnik mszalny, oprac. G.M. Skop, Katowice $1998^{8}$, s. 411.

${ }^{10}$ EE 19.

11 Por. Jan Paweł II, List apostolski Mane nobiscum Domine, 07.10.2004, „L'Osservatore Romano", wyd. pol. 269(2005), nry 5 i 19 (dalej: MnD).

${ }^{12}$ Por. A. Durak, Właczeni w kult eucharystyczny Kościoła, „Collectanea Theologica” 1(1997), s. 146.

${ }^{13} \mathrm{EE} 25$. 
wyrażająca się w duchu ,umywania nóg” (por. J 13,1-20) stanowi właściwe i najbardziej prawdziwe kryterium „eucharystyczności” życia wyznawców Chrystusa $^{14}$. Chrześcijanin z Eucharystii czerpie siłę potrzebną do tego, by być rzecznikiem komunii, pokoju i solidarności we wszystkich okolicznościach życia $^{15}$.

Jezus bardzo wyraźnie i mocno mówił swoim uczniom: „Jeżeli nie będziecie spożywali Ciała Syna Człowieczego i nie będziecie pili Krwi Jego, nie będziecie mieli życia w sobie" (J 6,53). Oznacza to, że bez kształtowania w sobie duchowości eucharystycznej, chrześcijanin praktycznie skazuje samego siebie na powolne „obumieranie”. Choć słowa Jezusa trzeba odnieść przede wszystkim do przyjmowania Komunii Świętej, to jednak nie można ich oddzielać od adoracji Najświętszego Sakramentu, dokonującej się podczas obrzędu wystawienia. Komunia Święta i adoracja są ze sobą ściśle powiązane i druga w naturalny sposób wypływa z pierwszej. Natomiast pierwsza daje głęboką motywację i uzasadnienie dla drugiej. Kościół żyje dzięki Eucharystii, pozbawiony tego Daru traci swój najważniejszy element konstytutywny i jest skazany na unicestwienie. Dotyczy to nie tylko Kościoła w ogólności, ale odnosi się to do każdego pojedynczego chrześcijanina. Mistyczne Ciało Chrystusa nie może bowiem rodzić się i rozwijać inaczej jak tylko wokół realnego Jego Ciała, jakim jest Eucharystia ${ }^{16}$.

Przytoczone argumenty ukazują, jak ogromną rolę w życiu chrześcijańskim odgrywa kult eucharystyczny, sprawowany również poza Mszą św. Miejsce, jakie winien on zajmować w hierarchii wartości każdego ucznia Chrystusa, odzwierciedla szacunek wobec tej Tajemnicy. Dodatkowo większej rangi takiemu spotkaniu z Jezusem nadają pragnienia i tęsknoty wynikające z ograniczoności ludzkiej natury.

\section{Rozwój i ożywienie kultu eucharystycznego drogą do pogłębienia wiary, nadziei i miłości}

Konieczność kultu eucharystycznego dla właściwego życia wyznawców Chrystusa, a co się z tym wiąże, także dla wzrostu Kościoła, wymaga nieustannej troski o jego rozkwit. Pomimo odnowy kultu Eucharystii przez Sobór Watykański II trzeba stwierdzić, że pozamszalny kult eucharystyczny znacznie osłabł i często jest niewłaściwie rozumiany i celebrowany. Stąd rodzi się

14 Por. EE 20; MnD 28.

15 Por. MnD 27.

16 Por. P. Socha, Pobożność eucharystyczna dzisiaj, „Studia Theologica Varsaviensia” 1(1987) s. 196. 
pilny postulat przywracania utraconych nabożeństw eucharystycznych oraz pogłębiania tych, które są praktykowane we wspólnotach parafialnych ${ }^{17}$.

Chcąc wzmocnić i pogłębić ten wymiar życia Kościoła, należy przede wszystkim być wewnętrznie przekonanym o konieczności oddawania czci i adoracji Najświętszego Sakramentu. Działania duszpasterskie winny podążać w tym kierunku, aby ukazywać wiernym najpierw nieocenione korzyści duchowe płynące ze spotkania z Chrystusem eucharystycznym. Stąd w przepowiadaniu oraz w katechezie zawsze trzeba łączyć uczestnictwo w Eucharystii, przyjmowanie Komunii Świętej oraz adorację Najświętszego Sakramentu ${ }^{18}$.

Na pewno pierwsze działania w przezwyciężeniu pewnego kryzysu kultu Eucharystii poza Mszą Świętą, a zwłaszcza adoracji Najświętszego Sakramentu, powinny prowadzić do ścisłego powiązania wystawienia Najświętszego Sakramentu z Ofiarą Nowego Przymierza. Adoracja bowiem winna wchodzić w sam przebieg Eucharystii i być jej naturalną kontynuacją. Dla ukazania tego nierozerwalnego związku można tam, gdzie odprawia się kilka Mszy św. w ciągu dnia, wprowadzić godzinną adorację między kolejnymi mszami. Jednocześnie trzeba unikać $\mathrm{w}$ tym przypadku przesadnego przedstawiania wartości adoracji ${ }^{19}$.

Kolejnym elementem czy propozycją rozwoju kultu adoracji Najświętszego Sakramentu jest tworzenie przestrzeni adoracyjnej. Potrzebna, a nawet konieczna, staje się tutaj zmiana mentalności osób odpowiedzialnych za omawiany obrzęd. Bardzo często zrozumiała obawa przed ewentualną kradzieżą i profanacją Świętych Postaci wywołuje bowiem uboczny skutek w postaci uniemożliwienia wiernym adoracji Eucharystii. Niestety, niekiedy ten argument jest tylko wymówką i usprawiedliwieniem braku potrzeby adoracji przez osoby, które winny ją promować. Zamknięcie świątyń staje się wówczas doskonałym sposobem na odzwyczajenie ludzi od nawiedzania Najświętszego Sakramentu. Sposobem rozwiązania takiego problemu może być wydzielenie do tego celu krypty lub kaplicy z kratą ${ }^{20}$. Poza tym dziś istnieją bardzo nowo-

${ }^{17}$ Por. W. Miziołek, Duszpasterstwo eucharystyczne, Eucharystia, red. J. Krucina, Wrocław 1987, s. 236. Zjawisko to może stanowić swego rodzaju reakcję na pewien przesyt wymiaru kultu eucharystycznego, jaki miał miejsce począwszy od Soboru Trydenckiego i brak jego właściwego rozumienia. Natomiast przeciwnicy odnowy liturgicznej i osoby sceptycznie do niej nastawione właśnie wobec reformy wysuwają zarzut o „likwidację” kultu Eucharystii, a przynajmniej lekceważenie go. Trzeba jednak powiedzieć, że takie stawianie sprawy zdradza zupełną nieznajomość dokumentów soborowej odnowy. Por. R. Zielasko, Teologiczne zasady ksztaltowania kultu eucharystycznego, „Collectanea Theologica” 2(1968), s. 49.

${ }_{18}$ Por. R. Rak, Eucharystia w życiu chrześcijańskim. Studium teologiczno-pastoralne o integralnym rozumieniu i petnym przeżywaniu Eucharystii, Katowice 1984, s. 189-191.

${ }^{19}$ Por. W. Miziołek, Duszpasterstwo eucharystyczne, art. cyt., s. 237.

${ }^{20}$ Por. S. Schudy, Duszpasterstwo liturgiczne w świetle dokumentów roboczych II Polskiego Synodu Plenarnego. Refleksje duszpasterza, Ateneum Kapłańskie 525(1996), s. 198. Dodać w tym miejscu należy, że tworzenie w świątyniach oddzielnych kaplic przeznaczonych do przechowywania 
czesne instalacje chroniące i uniemożliwiające dokonanie rabunku czy profanacji, a jednocześnie pozwalające na adorację wystawionego Najświętszego Sakramentu ${ }^{21}$. W związku z tym ważne zadanie do spełnienia ma działalność katechetyczna. Należy bowiem w taki sposób formować dzieci i młodzież, aby ukształtować w nich pragnienie wstępowania do świątyni przed zajęciami szkolnymi czy po nich na chwilę osobistej modlitwy ${ }^{22}$.

Bardzo pomocne w rozwoju kultu eucharystycznego są wszelkiego rodzaju nabożeństwa adoracyjne. W tym miejscu należy wskazać na ich ogromnie ważne zadanie w procesie wzrostu świadomości eucharystycznej u wiernych. Prawidłowa celebracja tychże nabożeństw oraz ich właściwe odniesienie do Eucharystii stwarza czynnik mogący budzić najważniejsze cnoty teologalne, czyli wiarę, nadzieję i miłość u osób adorujących Chrystusa. Podobną rolę mogą odgrywać procesje teoforyczne, szczególnie ta, która jest organizowana z okazji uroczystości Najświętszego Ciała i Krwi Chrystusa ${ }^{23}$.

Bardzo ważnym elementem, mogącym odnowić pobożność eucharystyczną u wiernych, będą zalecane wielokrotnie przez Kościół doroczne całodzienne adoracje Najświętszego Sakramentu. Taka praktyka nie ogranicza się tylko do jednej wspólnoty parafialnej, ale - zwłaszcza w dużych miastach - zdecydowanie przekracza jej ramy. Troska o jej przeprowadzenie wymaga wówczas współpracy wszystkich duszpasterzy. Ponadto przepisy zachęcają do organizowania wspólnotowej adoracji w każdej parafii raz w miesiącu w ustalonym dniu. Należy także propagować godzinną adorację w ciągu tygodnia ${ }^{24}$.

Ważne jest również prawidłowe przygotowanie i przeprowadzenie adoracji Najświętszego Sakramentu. Pewną pomoc może stanowić uzupełnienie adoracji Ciała Pańskiego o rozważania tajemnicy Eucharystii. Wielu cennych uwag dotyczących sposobu prowadzenia nabożeństw z wystawionym Najświętszym Sakramentem dostarcza nam wprowadzenie teologiczno-pastoralne do księgi zatytułowanej Komunia Święta i kult tajemnicy eucharystycznej poza Mszą Święta. Najpierw dokument przypomina, że wystawienie Najświętszego

i adoracji Najświętszej Eucharystii stanowi jeden z ważniejszych elementów posoborowej odnowy kultu eucharystycznego. Zob. Kongregacja Obrzędów, Instrukcja Eucharisticum mysterium, 25.05.1967, w: To czyńcie na moja pamiatkę. Eucharystia $w$ dokumentach Kościoła, oprac. J. Miazek, Warszawa 1987, n. 53, s. 184-185.

${ }^{21}$ Jako dodatkowe zabezpieczenie można również odnowić dawny zwyczaj Straży Honorowej. Jej członkowie, zgodnie $\mathrm{z}$ harmonogramem dyżurów modlitewnych, spędzaliby określone godziny na adoracji, a jednocześnie pilnowaliby kościoła. Por. S. Schudy, Duszpasterstwo liturgiczne w świetle dokumentów roboczych II Polskiego Synodu Plenarnego. Refleksje duszpasterza, art. cyt., s. 198.

${ }^{22}$ Por. II Polski Synod Plenarny, Liturgia Kościoła po Soborze Watykańskim II, w: II (Drugi) Polski Synod Plenarny (1991-1999), Poznań 2001, s. 189-216.

${ }^{23}$ Por. W. Miziołek, Duszpasterstwo eucharystyczne, art. cyt., s. 237-238.

${ }^{24}$ Polski Synod Plenarny, Liturgia Kościoła po Soborze Watykańskim II, art. cyt., s. 100-101.. 
Sakramentu ma prowadzić do uznania cudownej obecności Chrystusa w Eucharystii oraz do zjednoczenia z Nim. Także tutaj przypomniano, że podczas wystawienia nic nie może przysłaniać pragnienia Chrystusa, który ustanowił Eucharystię jako pokarm, lekarstwo i pokrzepienie ${ }^{25}$. W dalszej części spotykamy zalecenie, aby w kościołach i kaplicach, w których na stałe przechowuje się Najświętszy Sakrament, odbywało się każdego roku uroczyste jego wystawienie, aby wierni mogli gorliwiej rozważać i adorować tajemnicę Eucharystii ${ }^{26}$. Dokument zauważa, że w ważnej i powszechnej potrzebie biskup miejsca może nakazać modlitwy błagalne przed wystawionym Najświętszym Sakramentem, trwające przez dłuższy czas ${ }^{27}$.

Porządek nabożeństw z wystawionym Najświętszym Sakramentem powinien uwzględniać miejsce dla słowa Bożego, śpiewu oraz modlitwy wspólnej i w ciszy. Zakazuje się wystawiania, którego celem byłoby tylko udzielenie błogosławieństwa. Dotyczy to zarówno Eucharystii, jak i innych nabożeństw ${ }^{28}$.

Rubryki zawarte w Obrzędzie wystawienia i błogosławieństwa eucharystycznego zalecają, aby podczas wystawienia tak ułożyć modlitwy, śpiewy i czytania biblijne, aby adorujący mogli całą uwagę skupić na Chrystusie obecnym w Najświętszym Sakramencie. W tym miejscu mamy też zachętę, aby przed Najświętszym Sakramentem, wystawionym na dłuższy czas, celebrować jakąś część Liturgii godzin, a zwłaszcza godzin głównych, czyli jutrznię i nieszpory ${ }^{29}$.

Ożywieniu i pogłębieniu kultu eucharystycznego w poszczególnych wspólnotach parafialnych sprzyja istnienie i działalność bractw adoracyjnych, których powszechne zakładanie zalecił już Sobór Trydencki ${ }^{30}$. Wspólnoty takie, ukazują obecną we współczesnym człowieku szczególną potrzebę odczucia sacrum i ducha kontemplacji. Właśnie to stanowi doskonałą okazję do pogłębienia pobożności eucharystycznej. Postawa członków bractwa ma ponadto charakter świadectwa wobec pozostałych wiernych. Wspomaga ducha

${ }^{25}$ Rytuał Rzymski, Komunia Święta i kult tajemnicy eucharystycznej poza Msza Święta. Dostosowane do zwyczajów diecezji polskich, Katowice 1985, nr 58.

${ }^{26}$ Por. tamże, nr 62.

27 Tamże, nr 63.

${ }^{28}$ Por. tamże, nr 65.

${ }^{29}$ Por. tamże, nry 71-72.

${ }^{30}$ Wywodzą się one ze średniowiecznych bractw Najświętszego Sakramentu, których głównym celem było szerzenie kultu Eucharystii. Do szczegółowych obowiązków członków bractwa należała adoracja i troska o godny sposób przechowywania Ciała Pańskiego oraz zanoszenia Go chorym. Zadanie ich stanowiło również podtrzymywanie ognia wiecznej lampki, a także organizacja procesji teoforycznej w piątek oktawy Bożego Ciała. Por. W. Malej, T. Widełka, Adoracja Najświętszego Sakramentu, w: Encyklopedia katolicka, red. F. Grglewicz, R. Łukaszyk, Z. Sułowski, t. I, Lublin 1995, kol. 102-104. 
nowej ewangelizacji, która winna dokonywać się przez pogłębione życie eucharystyczne, gdyż tylko wtedy będzie owocna i trwała.

\section{Szczególne okoliczności adoracji Najświętszego Sakramentu pogłębiające życie religijne}

Od początku istnienia Kościoła odpowiedzialność za kult eucharystyczny spoczywa na całym Kościele i wszędzie, gdzie on istnieje. Jednak w Mistycznym Ciele Chrystusa istnieją pewne grupy, które można by określić jako uprzywilejowane $\mathrm{w}$ realizowaniu tego zadania. Na takie właśnie kategorie osób wskazują dokumenty powstałe po Soborze Watykańskim II.

Spośród omawianych grup najczęściej wymienia się wspólnoty zakonne. Zalecenia skierowane do zakonów, zgromadzeń i instytutów życia konsekrowanego wyrażają troskę o rozwój ich życia duchowego przez częste praktykowanie adoracji Najświętszego Sakramentu ${ }^{31}$. Rytuat rzymski poświęca wiele uwagi adoracji Najświętszego Sakramentu w tych środowiskach, wskazując ją jako środek do rozwijania własnej pobożności oraz do rozwijania ducha jedności i braterstwa wśród członków domu zakonnego. Tutaj też kult należny Najświętszemu Sakramentowi uzyskuje doskonalszą formę ${ }^{32}$. Mówiąc o pewnych uprzywilejowanych grupach, nie można zapominać o powszechnym wymiarze kultu chrześcijańskiego. Oznacza to, że te uprzywilejowane grupy muszą przyjąć te formy adoracji, które są zgodne z duchem liturgii. Wspólnotowe uwielbienie Chrystusa Eucharystycznego nie wyklucza osobistego trwania przed Najświętszym Sakramentem. Na duże uznanie zasługuje praktyka adoracji, w której członkowie wspólnoty kolejno biorą udział pojedynczo lub po dwie osoby ${ }^{33}$. Mówiąc o zaletach adoracji Najświętszego Sakramentu, św. Jan Paweł II, tak pisał wspólnot zakonnych: „Wy, osoby konsekrowane, powołane przez samą swoją konsekrację do intensywnej kontemplacji, pamiętajcie, że Jezus w tabernakulum oczekuje, by napełnić wasze serca tym głębokim doświadczeniem swojej przyjaźni, która jako jedyna może nadać sens i pełnię waszemu życiu" ${ }^{34}$.

Następną grupą ludzi, którzy są w sposób szczególny wezwani do adoracji Najświętszego Sakramentu, są kapłani oraz alumni przygotowujący się w se-

${ }^{31}$ Zob. Jan Paweł II, Adhortacja apostolska Vita consecrata, 25.03.1996, 95, w: Adhortacje apostolskie Ojca Świętego Jana Pawła II, Kraków 1996, s. 925-926.

32 Komunia Święta i kult Tajemnicy Eucharystycznej poza Msza Święta dostosowane do zwyczajów diecezji polskich, Katowice 1985, n. 66.

${ }^{33}$ Por. tamże.

${ }^{34} \mathrm{MnD} 30$. 
minariach duchownych do przyjęcia święceń ${ }^{35}$. W pełni zrozumiały jest fakt, że Eucharystia stanowi niezbędny i fundamentalny element formacji seminaryjnej. Ogromną wagę przywiązuje się tu zarówno do aktywnego uczestnictwa we Mszy Świętej, jak i do adoracji Chrystusa ukrytego w Najświętszym Sakramencie. Wszelkie inicjatywy i działania formacyjne pod tym względem winny dążyć do tego, by w kandydacie do kapłaństwa wykształcić „,pragnienie kontemplacji i adoracji Chrystusa realnie obecnego pod eucharystycznymi postaciami" "36. Do tychże osób odnosi się wezwanie Jana Pawła II, by chętnie trwały na modlitwie przed tabernakulum i prowadziły długi dialog z Jezusem Eucharystią ${ }^{37}$.

Jan Paweł II we właściwie rozumianej adoracji Najświętszego Sakramentu widział dużą pomoc w duszpasterstwie osób żyjących w związkach niesakramentalnych. Osoby te nie mogą w pełni uczestniczyć w Eucharystii, ale często odczuwają głód Chrystusa Eucharystycznego. Nie są też wyłączone od miłości Chrystusa i Kościoła. Właśnie adoracja Najświętszego Sakramentu stwarza im możliwość kontemplacji oblicza Chrystusa, czyli pewien rodzaj Komunii duchowej $^{38}$.

Posoborowe dokumenty Kościoła, obok wskazania grup szczególnie odpowiedzialnych za kult eucharystyczny, wiele uwagi poświęcają również okolicznościom sprzyjającym ekspozycji oraz adoracji Najświętszego Sakramentu. Kościół zachęca do większego uwydatnienia związku samej Eucharystii z kultem oddawanym jej extra Missam poprzez wystawianie do adoracji Hostii konsekrowanej podczas bezpośrednio poprzedzającej ekspozycję Mszy Świętej Tego rodzaju formy adoracji Najświętszego Sakramentu stwarzają różne uroczystości czy obchody w ciągu całego roku liturgicznego.

Na pierwszym miejscu należy wymienić uroczystość Najświętszego Ciała i Krwi Chrystusa. Urządzana w tym dniu procesja stanowi publiczny wyraz wiary i pobożności ludu gromadzącego się wokół Tajemnicy Eucharystycznej ${ }^{39}$. Obrzęd wystawienia Najświętszego Sakramentu, ściśle związany z celebracją Mszy Świętej, ma wówczas elementy typowe dla tej uroczystości. Niesione podczas wspomnianej procesji Ciało Pańskie jest wystawiane na czterech przygotowanych w tym celu ołtarzach. Przy każdym z nich ma miejsce śpiew hymnu, umieszczenie Sanctissimum na tronie i okadzenie Go

${ }^{35}$ Zob. Polski Synod Plenarny, Liturgia Kościoła po Soborze Watykańskim I, art. cyt., s. 103.

${ }^{36}$ Jan Paweł II, Adhortacja apostolska Pastores dabo vobis, 25.03.1992, n. 48, w: Adhortacje apostolskie Ojca Świętego Jana Pawła II, Kraków 1996, s. 616.

${ }^{37} \mathrm{Zob} . \mathrm{MnD} 30$.

${ }^{38}$ Zob. Jan Paweł II, Adhortacja apostolska Familiaris consortio, 22.11.1981, n. 84, w: Adhortacje apostolskie Ojca Świętego Jana Pawła II, Znak, Kraków 1996, s. 201-203.

${ }^{39}$ Zob. Komunia Święta i kult Tajemnicy Eucharystycznej poza Msza Święta dostosowane do zwyczajów diecezji polskich, dz. cyt., n. 77. 
oraz proklamacja Ewangelii. Poszczególne stacje kończy wspólna modlitwa, okadzenie Najświętszej Eucharystii oraz specjalna oracja. Na zakończenie procesji umieszcza się monstrancję na głównym ołtarzu. Następuje wówczas okadzenie, śpiew hymnu Ciebie, Boga, wysławiamy, kolejne okadzenie, oracja oraz błogosławieństwo i repozycja Najświętszego Sakramentu ${ }^{40}$.

Kolejne sprzyjające okoliczności do takich adoracji stwarzają celebracje Triduum Paschalnego. Czas ten obfituje w liczne momenty związane z ekspozycją i adoracją Najświętszego Sakramentu. Po raz pierwszy występuje ona po Mszy Wieczerzy Pańskiej w Wielki Czwartek. Celebrans po modlitwie postcommunio klęka i okadza Najświętszy Sakrament. Następnie otrzymuje welon, bierze puszkę z Ciałem Pańskim i okrywszy ją welonem, wśród śpiewu hymnu Staw języku, tajemnicę, udaje się w procesji do miejsca przechowania. Tam w specjalnie przygotowanym tabernakulum kapłan umieszcza puszkę i klęcząc, okadza Najświętszy Sakrament. Śpiewane są wówczas dwie ostatnie zwrotki hymnu, po czym zamyka się tabernakulum. Adoracja Corpus Christi w kaplicy przechowania po północy nie może już mieć uroczystego charakteru ${ }^{41}$.

Podczas liturgii Wielkiego Piątku przenosi się Najświętszy Sakrament do tak zwanego Grobu Pańskiego. Na czas adoracji umieszczonego tam Corpus Christi monstrancja zostaje okryta przezroczystym białym welonem ${ }^{42}$. Stan taki trwa aż do rozpoczęcia celebracji Wigilii Paschalnej, kiedy to następuje repozycja Najświętszego Sakramentu bez udzielenia Nim błogosławieństwa ${ }^{43}$.

Po raz kolejny obrzęd wystawienia pojawia się przy okazji uroczystej procesji rezurekcyjnej. Podczas niej kapłan ubrany w ornat i okryty welonem naramiennym, wśród śpiewów obnosi w monstrancji Ciało Pańskie wokół świątyni. Schemat zakończenia tej procesji wykazuje pewne podobieństwo do poprzedniego przypadku ${ }^{44}$.

Kolejną wyjątkową okolicznością stanowiącą możliwość uroczystej adoracji Najświętszego Sakramentu w połączeniu z Eucharystią stwarza uroczystość odpustowa każdej parafii. Struktura obrzędu wystawienia Najświętszej Eucharystii nie odbiega jednak wówczas od przewidzianej w Rytuale. Uroczysta procesja eucharystyczna kończąca celebrację wraz ze śpiewem hymnu może stanowić tu nawiązanie do wspomnianej procesji na cześć zmartwychwstałego Pana.

Przytoczone przykłady ukazują różnorodność i duże bogactwo sytuacji związanych z możliwością ekspozycji i adoracji Najświętszego Sakramentu. Należy zauważyć, że liturgiczne obchody, które domagają się ekspozycji i ad-

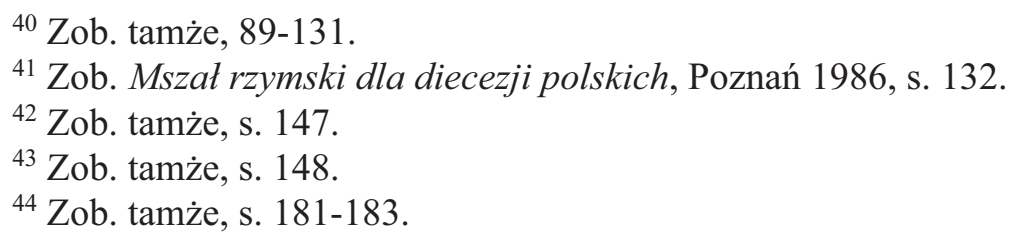


oracji, zalicza się do najważniejszych w całym roku liturgicznym. Uroczystości te gromadzą zwykle większą grupę wiernych w kościele. Odpowiednie przygotowanie i poprowadzenie adoracji Najświętszego Sakramentu może pomóc wiernym w głębszym zjednoczeniu z Chrystusem Eucharystycznym oraz pogłębić ich wiarę, nadzieję i miłość.

$$
* * *
$$

Podsumowując, trzeba podkreślić, że mimo pewnego „ostudzenia” kultu Eucharystii poza Mszą Świętą po Soborze Watykańskim II w polskim Kościele adoracja wystawionego Najświętszego Sakramentu cieszy się jeszcze dość dużą popularnością u wiernych. Można również zauważyć, że tam gdzie odbywa się adoracja wieczysta lub kościoły są otwarte przez cały dzień, wierni często przychodzą oddać cześć Chrystusowi Eucharystycznemu. To na pewno bardzo cieszy. Trzeba jednak dokonać pewnego wysiłku, żeby kult adoracyjny Najświętszego Sakramentu bardziej powiązać z Eucharystią i sprawować go w sposób właściwy, zwłaszcza w przypadku nabożeństw ludowych ku czci świętych. Nie ulega wątpliwości, że poprawnie prowadzone adoracje Najświętszego Sakramentu będą pobudzały u wiernych głód Eucharystii i pragnienie głębszego zjednoczenia z Chrystusem, żyjącym w Kościele. Konsekwencją życia w Chrystusie będzie życie żywą wiarą, nadzieją i miłością. Człowiek systematycznie adorujący Chrystusa obecnego w Najświętszym Sakramencie staje się dojrzałym uczniem i świadkiem Zbawiciela.

\section{THE CULT OF EUCHARISTIC ADORATION AS THE SOURCE OF AUTHENTIC CHRISTIAN MORAL ATTITUDES}

\section{Summary}

The next most popular form of Eucharist, aside from Holy Mass, is the adoration of The Highest Sacrament. The article depicts the great force coming from the adoration and its influence on shaping Christian moral attitudes. A prayer in front of Christ, present in the Eucharist, is a necessity for building one's sanctity and living with the rules of the Gospel. It also opens new ways of Christian lifestyle and shows proof of, hidden in The Highest Sacrament, Christ's eucharistic love. This personal experience with the Saviour is a real spring of Christian moral attitudes, which are faith, hope and love. The adoration of The Highest Sacrament strengthens the believers on their way towards the eternity and allows them to anticipate it. 
Słowa kluczowe: Eucharystia; Najświętszy Sakrament; adoracja; zjednoczenie; wiara; nadzieja; miłość

Keywords: Eucharist; The Highest Sacrament; adoration; unification; faith; hope; love

\section{BIBLIOGRAFIA}

\section{Źródła liturgiczne}

Exsultate Deo. Śpiewnik mszalny, oprac. G.M. Skop, Katowice $1998^{8}$.

Mszat rzymski dla diecezji polskich, Poznań 1986.

Rytuat Rzymski. Komunia święta i kult tajemnicy eucharystycznej poza Msza świętą: dostosowane do zwyczajów diecezji polskich, Księgarnia Św. Jacka, Katowice 1985.

\section{Dokumenty Nauczycielskiego Urzędu Kościoła}

Jan Paweł II, Adhortacja Apostolska Familiaris consortio, 22.11.1981, w: Adhortacje apostolskie Ojca Świętego Jana Pawła II, Kraków 1996, s. 89-208.

Jan Paweł II, Adhortacja Apostolska Pastores dabo vobis, 25.03.1992, w: Adhortacje apostolskie Ojca Świętego Jana Pawła II, Kraków 1996,s. 517-684.

Jan Paweł II, Adhortacja Apostolska Vita consecrata, 25.03.1996, w: Adhortacje apostolskie Ojca Świętego Jana Pawła II, Znak, Kraków 1996,s. 801-946.

Jan Paweł II, Encyklika o Eucharystii w życiu Kościoła Ecclesia de Eucharistia, 17.04.2003, Poznań 2003.

Jan Paweł II, List Apostolski Mane nobiscum Domine, 07.10.2004, „L'Osservatore Romano”, wydanie polskie 269(2005), s. 4-11.

Kongregacja Obrzędów, Instrukcja Eucharisticum mysterium, 25.05.1967, w: To czyńcie na moja pamiatkę. Eucharystia w dokumentach Kościoła, oprac. J. Miazek, Warszawa 1987, s. 154-190.

Paweł VI, Encyklika Mysterium fidei, w: To czyńcie na moja pamiątkę. Eucharystia w dokumentach Kościoła, oprac. J. Miazek, Warszawa 1987, s. 13-32.

II Polski Synod Plenarny, Liturgia Kościoła po Soborze Watykańskim II, w: II (Drugi) Polski Synod Plenarny (1991-1999), Poznań 2001, s. 189-216.

XI Zwyczajne Zgromadzenie Biskupów, Eucharystia: źródto i szczyt życia i posłannictwa Kościoła. Zarys, Watykan 2004.

\section{Opracowania}

Blaza M., Wszyscy jesteśmy ludem Eucharystii, „Przegląd Powszechny” 922(1998), s. 265-276.

Durak A., Teksty euchologijne jako źródlo teologiczne (euchologia liturgiczna), RBL 1(1994), s. 33-37 .

Liguori A.M., Visite al. SS. Sacramento ed a Maria Santissima. Introduzione, w: Opere ascetiche, Avellino 2000.

Malej W., Widełka T., Adoracja Najświętszego Sakramentu, w: Encyklopedia Katolicka, red. F. Grglewicz, R. Łukaszyk, Z. Sułowski, t. I, Lublin 1995, kol. 102-104.

Miziołek W., Duszpasterstwo eucharystyczne, w: Eucharystia, red. Krucina J., Wrocław 1987, s. 217-238. 
Rak R., Eucharystia w życiu chrześcijańskim. Studium teologiczno-pastoralne o integralnym rozumieniu i pelnym przeżywaniu Eucharystii, Katowice 1984

Schudy S., Duszpasterstwo liturgiczne w świetle dokumentów roboczych II Polskiego Synodu Plenarnego. Refleksje duszpasterza, „Ateneum Kapłańskie” 525(1996), s. 189-205.

Socha P., Pobożność eucharystyczna dzisiaj, „Studia Theologica Varsaviensia” 1(1987), s. 183-197.

Zielasko R., Teologiczne zasady ksztattowania kultu eucharystycznego, „Collectanea Theologica” 2(1968), s. 41-53.

Dariusz KwiatKowski, dr hab. prof. UAM; prezbiter diecezji kaliskiej, kierownik Zakładu Liturgiki i Homiletyki na Wydziale Teologicznym Uniwersytetu im. Adama Mickiewicza w Poznaniu, liturgista, wykładowca liturgiki w Wyższym Seminarium Duchownym w Kaliszu i Arcybiskupim Seminarium Duchownym w Poznaniu. Autor kilku monografii, w tym dwóch tomów ćwiczeń z liturgiki dla studentów teologii oraz około 70 artykułów z zakresu liturgiki, szczególnie teologii liturgii i odnowionej po Vaticanum II liturgii sakramentów i sakramentaliów, a także kultu św. Józefa. Przewodniczący Wydziału Liturgii i Dyscypliny Sakramentów w kurii diecezji kaliskiej. E-mail: kwiatkowski@post.p 